\title{
Orally Administered Prion Protein Is Incorporated by M Cells and Spreads into Lymphoid Tissues with Macrophages in Prion Protein Knockout Mice
}

\author{
Ikuro Takakura, ${ }^{*}$ Kohtaro Miyazawa, ${ }^{*}$ \\ Takashi Kanaya, ${ }^{*}$ Wataru Itani, ${ }^{*}$ \\ Kouichi Watanabe, ${ }^{*}$ Shyuichi Ohwada, ${ }^{*}$ \\ Hitoshi Watanabe, ${ }^{*}$ Tetsuya Hondo, ${ }^{*}$ \\ Michael T. Rose, ${ }^{\dagger}$ Tsuyoshi Mori, ${ }^{\ddagger}$ Suehiro Sakaguchi, ${ }^{\neq}$ \\ Noriyuki Nishida, ${ }^{\S}$ Shigeru Katamine, ${ }^{\S}$ \\ Takahiro Yamaguchi, ${ }^{*}$ and Hisashi Aso* \\ From the Cellular Biology Laboratory, * Graduate School of \\ Agricultural Science, Toboku University, Sendai, Japan; the \\ Institute of Biological, Environmental and Rural Sciences, ${ }^{\dagger}$ \\ Aberystwyth University, Ceredigion, United Kingdom; the Division \\ of Molecular Neurobiology, ${ }^{\ddagger}$ The Institute for Enzyme Research, \\ The University of Tokushima, Tokushima, Japan; and the \\ Department of Molecular Microbiology and Immunology, ${ }^{\lessgtr}$ Nagasaki \\ University Graduate School of Medicine, Nagasaki, Japan
}

Transmissible spongiform encephalopathies are fatal neurodegenerative diseases. Infection by the oral route is assumed to be important, although its pathogenesis is not understood. Using prion protein (PrP) knockout mice, we investigated the sequence of events during the invasion of orally administered PrPs through the intestinal mucosa and the spread into lymphoid tissues and the peripheral nervous system. Orally administered PrPs were incorporated by intestinal epitheliocytes in the follicle-associated epithelium and villi within 1 hour. PrPpositive cells accumulated in the subfollicle region of Peyer's patches a few hours thereafter. PrP-positive cells spread toward the mesenteric lymph nodes and spleen after the accumulation of PrPs in the Peyer's patches. The number of PrP molecules in the mesenteric lymph nodes and spleen peaked at $\mathbf{2}$ days and $\mathbf{6}$ days after inoculation, respectively. The epitheliocytes in the follicle-associated epithelium incorporating PrPs were annexin V-positive microfold cells and PrP-positive cells in Peyer's patches and spleen were $\mathrm{CD11b}$-positive and $\mathrm{CD14}$-positive macrophages. Additionally, PrP-positive cells in Peyer's patches and spleen were detected in the vicinity of peripheral nerve fibers in the early stages of infection. These results indicate that orally delivered PrPs were incorporated by microfold cells promptly after challenge and that macrophages might act as a transporter of incorporated PrPs from the Peyer's patches to other lymphoid tissues and the peripheral nervous system. (Am J Pathol 2011, 179:1301-1309; DOI: 10.1016/j.ajpath.2011.05.058)

Transmissible spongiform encephalopathies (TSEs), or prion diseases, are fatal neurodegenerative diseases that infect humans and both wild and domestic animals. They include Creutzfeldt-Jakob disease (CJD) in humans, scrapie in sheep, and bovine spongiform encephalopathy (BSE) in cattle. ${ }^{1}$ The common neuropathological features within the central nervous system (CNS) of TSEs are seen as a spongiform pathology, neuronal loss, ${ }^{2}$ glial activation, ${ }^{3}$ and the accumulation of an abnormal and protease-resistant conformer of the scrapie-associated prion proteins (PrP-res or $\left.\mathrm{PrP}^{\mathrm{Sc}}\right),{ }^{4}$ which are closely associated with the infection. ${ }^{5}$

It has been reported that variant CJD in humans is most likely to have occurred because of the transmission of BSE after the consumption of beef contaminated with the BSE agent. ${ }^{6}$ Therefore, the oral route of TSE infection is widely assumed to be important under natural conditions. Many of the infectious agents accumulate in the gut-associated lymphoid tissues (GALT) after oral infection, such as the Peyer's patches and mesenteric lymph nodes (MLN) before spreading to the $\mathrm{CNS}^{7}$ It is necessary for the infectious

Supported by a Grant-in-Aid for Scientific Research (21380170) from the Ministry of Education, Culture, Sports, Science and Technology (I.K., K.M., T.K., W.I., K.W., T.H., T.Y., and H.A.); BSE Control Project from the Ministry of Agriculture, Forestry and Fisheries (I.K., K.M., T.K., W.I., K.W., T.H., T.Y., and H.A.); and Cooperative Research Grant of the Institute for Enzyme Research, the University of Tokushima (T.M. and S.S.).

Accepted for publication May 23, 2011.

Supplemental material for this article can be found at http://ajp. amjpathol.org or at doi: 10.1016/j.ajpath.2011.05.058.

Current address of I.T., Toxicology Research Laboratory, R\&D, Kissei Pharmaceuticals Co., Ltd., Nagano, Japan; of K.M., Prion Disease Research Center, National Institute of Animal Health, Ibaraki, Japan.

Address reprint requests to Hisashi Aso, Ph.D., Cellular Biology Laboratory, Graduate School of Agricultural Science, Tohoku University, 1-1 Tsutsumidori Amamiyamachi, Aoba-ku, Sendai, 981-8555 Japan. E-mail: asosan@bios.tohoku.ac.jp. 
agents to cross the intestinal epithelium before they can accumulate in the GALT. In addition, there are microfold cells ( $M$ cells) within the follicle-associated epithelium (FAE) that are specialized for the transepithelial transport of macromolecules and particles. ${ }^{8}$ One in vitro study has demonstrated that $\mathrm{M}$ cells actively transcytose the scrapie agents into the basolateral side of the epithelium. ${ }^{9}$ However, it is still a matter of controversy as to whether $\mathrm{M}$ cells may be involved in the in vivo transport of the infectious agents across the intestinal epithelium. After alimentary uptake of the infectious agents, they accumulate in the GALT and the lymphoreticular systems (eg, the spleen and other peripheral lymph nodes) long before they are detected in the CNS. ${ }^{10}$ As the GALT and the lymphoreticular systems are highly innervated, they are believed to be important sites for the infectious agents to gain contact with the nervous system (ie, neuroinvasion). ${ }^{11}$ Once neuroinvasion occurs, the infectious agents reach their initial CNS target sites by spreading in a retrograde direction along efferent nerve fibers. ${ }^{12}$

In the lymphoid tissues, it is believed that the macrophages, dendritic cells (DCs), and follicular dendritic cells (FDCs) are involved in the transportation and replication of the infectious agents. Macrophages are prevalent candidates for both spread ${ }^{13}$ and clearance ${ }^{14}$ of the infectious agents. DCs can capture and retain protein antigens in a nondegraded state. ${ }^{15,16}$ These characteristics suggest that the macrophages and DCs may act as a transporter of the infectious agents from the gut to lymphoid tissues. FDCs express high levels of cellular $\operatorname{PrPs}\left(\mathrm{PrP}^{\mathrm{C}}\right)$, and therefore an early accumulation of $\mathrm{PrPSc}^{\mathrm{Sc}}$ is seen in them. ${ }^{17,18}$ Many studies of the alimentary pathogenesis of TSEs have been conducted to elucidate how infectious agents spread from the GALT to the CNS, although this has not been clearly determined yet. Therefore, the aim of the present study was to reveal the cells involved in the early stages of the pathogenesis of oral TSE infection, such as the sites of entry, spread, and neuroinvasion.

\section{Materials and Methods}

\section{Materials}

All procedures involving animals were conducted in accordance with the Guidelines for Animals Experimentation of Tohoku University, Nagasaki University, and the University of Tokushima. PrPc knockout mice (Ngsk Prnp ${ }^{0 / 0}$ mice, male, 3 weeks old $)^{19}$ were used in this study and supplied by BioResource Bank, the Institute for Enzyme Research, the University of Tokushima (Tokushima, Japan). Ngsk Prnp ${ }^{0 / 0}$ mice ectopically express doppel in the tissues where $\mathrm{PrP}^{\mathrm{c}}$ is expressed. ${ }^{20}$ However, it has been observed that the ectopic expression of doppel does not modulate prion accumulation in the brain of the mice. ${ }^{21,22}$ Therefore, Ngsk Prnp ${ }^{0 / 0}$ mice can be used to monitor the fate of orally administered PrPs incorparated from the gut lumen. All mice were clinically healthy and free of infectious disease.

In this study, we used a rabbit antibody against the sequence of amino acids between 1 and 50 at the N-terminus of human $\mathrm{PrP}^{\mathrm{C}}$ (diluted 1:300; IBL, Gunma, Japan $)^{18}$ to detect PrP-positive cells in Peyer's patches, $M L N$, and spleen. To identify the cell types of PrP-positive cells, we stained the Peyer's patches and spleen with various antibodies against specific cell phenotypes. These were CD45R/B220 for B cells, ${ }^{23}$ CD14 and CD11b for macrophages, ${ }^{24,25} \mathrm{CD} 3$ for $\mathrm{T}$ cells, ${ }^{26}$ Annexin $\mathrm{V}$ for $\mathrm{M}$ cells and DCs, ${ }^{27}$ and clusterin for $\mathrm{FDCs}^{28}$ (Table 1).

\section{Oral Inoculations of Brain Homogenate}

As a source of infection, we used Fukuoka-1 strain CJD derived from human Gerstmann-Sträussler-Scheinker disease. ${ }^{29}$ Brains were obtained from healthy ddY mice which were normal or at the terminal stage of disease or infected-ddY mice and then kept at $-80^{\circ} \mathrm{C}$. Brains were homogenized to $10 \%(\mathrm{w} / \mathrm{v})$ in cold PBS. PrP ${ }^{\circ}$ knockout mice were orally challenged with $200 \mu \mathrm{L}$ of brain homogenate using a sterile disposable oral gastric tube (FuchigamiKikai, Kyoto, Japan) and sacrificed at 15 and 30 minutes, 1 , 2, 4, 6, 8, and 10 hours, 2 and 6 days, and 4 and 10 weeks after the challenge. At each time point, Peyer's patches from the duodenum, jejunum, ileum, MLN, and spleen were obtained from three mice. All tissues were fixed in periodate lysine paraformaldehyde (PLP) overnight at $4^{\circ} \mathrm{C}$. The fixed samples were paraffin-embedded or snap-frozen in OCT compound (Sakura Finetechnical, Tokyo, Japan).

Table 1. Primary Antibodies Used in this Study

\begin{tabular}{|c|c|c|c|c|c|c|}
\hline Antibodies & Specificity & Species & Developed in & Clone name & Dilution & Products* \\
\hline $\begin{array}{l}\text { PrP } \\
\text { CD45R/B220 } \\
\text { CD14 } \\
\text { DC } \\
\text { FDC } \\
\text { CD3 }\end{array}$ & $\begin{array}{l}\text { Prion protein } \\
\text { B cells } \\
\text { Macrophages }^{23} \\
\text { Dendritic cells } \\
\text { Follicular dendritic cells } \\
\text { T cells }\end{array}$ & $\begin{array}{l}\text { Human } \\
\text { Mouse } \\
\text { Mouse } \\
\text { Mouse } \\
\text { Mouse } \\
\text { Mouse }\end{array}$ & $\begin{array}{l}\text { Rabbit } \\
\text { Rat } \\
\text { Rat } \\
\text { Rat } \\
\text { Rat } \\
\text { Goat }\end{array}$ & $\begin{array}{l}\text { RA3-6B2 } \\
\text { rmC5-3 } \\
\text { MIDC-8 } \\
\text { FDC-M1 }\end{array}$ & $\begin{array}{l}1: 300 \\
1: 1000 \\
1: 50 \\
1: 50 \\
1: 50 \\
1: 50\end{array}$ & $\begin{array}{l}\text { IBL } \\
\text { BD Pharmingen } \\
\text { BD Pharmingen } \\
\text { AbD Serotec } \\
\text { BD Pharmingen } \\
\text { Santa Cruz }\end{array}$ \\
\hline $\begin{array}{l}\text { CD11b } \\
\text { Annexin V }\end{array}$ & $\begin{array}{l}\text { Macrophages }{ }^{25} \\
\text { M cells and dendritic cells }{ }^{27}\end{array}$ & $\begin{array}{l}\text { Mouse } \\
\text { Human }\end{array}$ & $\begin{array}{l}\text { Rat } \\
\text { Goat }\end{array}$ & $\mathrm{M} 1 / 70$ & $\begin{array}{l}1: 300 \\
1: 50\end{array}$ & $\begin{array}{l}\text { AbD Serotec } \\
\text { Santa Cruz } \\
\text { Biotechnology }\end{array}$ \\
\hline Clusterin & Follicular dendritic cells ${ }^{28}$ & Mouse & Goat & & $1: 300$ & $\begin{array}{l}\text { Santa Cruz } \\
\text { Biotechnology }\end{array}$ \\
\hline PGP 9.5 & Protein gene product $9.5^{32}$ & Human & Rabbit & & & AbD Serotec \\
\hline
\end{tabular}

*Products from IBL (Gunma, Japan), BD Pharmingen (San Diego, CA), AbD Serotec (Oxford, UK), Santa Cruz Biotechnology (Santa Cruz, CA). $\mathrm{DC}$, dendritic cells; FDC, follicular dendritic cell; PGP, protein gene product; PrP, prion protein. 


\section{Immunohistochemistry}

Sections (3- $\mu \mathrm{m}$ thick) from paraffin-embedded tissues were mounted on silane-coated slides, de-paraffinized in xylene and rehydrated in a series of graded ethanol solutions and transferred to PBS. The slides were placed in Target Retrieval Solution (Dako, Carpinteria, CA) and heated in an autoclave at $121^{\circ} \mathrm{C}$ for 5 minutes as the antigen retrieval technique. ${ }^{18}$ After cooling, the slides were rinsed three times in PBS and the background blocking was performed with normal goat serum (Vector Laboratories, Burlingame, CA) for 20 minutes before incubation with a specific primary antibody. The sections were incubated with polyclonal anti-PrP ${ }^{c}$ antibody at $4^{\circ} \mathrm{C}$ overnight, rinsed five times in PBS, and incubated with biotinylated goat anti-rabbit IgG (diluted 1:200; Vector Laboratories) for 40 minutes. The sections were treated with an ABC-PO kit (Vector Laboratories) for 1 hour, visualized by 3, 3'-diaminobenzidine tetrahydrochloride (DAB) and then counterstained with Mayer's hematoxylin. Finally, the sections were observed for PrP-staining using light microscopy. To test the specificity of the immunostaining for murine tissue, negative controls were run in which the primary antibody was omitted or replaced with an irrelevant rabbit IgG purified with a protein A column (diluted 1:300, code \#17312, IBL) ${ }^{18}$ (see Supplemental Figure $\mathrm{S} 1$ at $h$ ttp://ajp.amjpathol.org).

\section{Immunohistochemical Re-Staining Method}

First, we dual-stained with polyclonal anti-PrP $\mathrm{P}^{\mathrm{C}}$ antibody and several anti-cell marker antibodies. Heating in an autoclave was used as the method of antigen retrieval, and then the slides could be stained with polyclonal anti-PrPc antibody, but not with several of the anti-cell marker antibodies. In contrast, after each treatment for the detection of several of the anti-cell markers, the slides nonspecifically stained with polyclonal anti-PrPc antibody; therefore, we immunohistochemically re-stained the sections using the same slides. ${ }^{18}$ Each re-stained section was re-stained once with an anti-cell marker antibody after the PrP staining.

Briefly, to identify the cell types staining positive for PrPs, 3- $\mu \mathrm{m}$-thick sections of Peyer's patches and $5-\mu \mathrm{m}$ thick sections of spleen were used for immunohistochemical re-staining. After immunohistochemical detection of challenged PrPs, the sections were observed by light microscope, and thereafter were stained for several cell marker antibodies. Pretreatment was needed to stain with anti-CD11b antibody and anti-annexin $\mathrm{V}$ antibody. To stain with anti-CD11b antibody, the sections were predigested with $0.0025 \%$ trypsin in $0.1 \%$ calcium chloride $(\mathrm{pH} 7.5)$ at $37^{\circ} \mathrm{C}$ for 5 minutes. For staining with antiannexin $\mathrm{V}$ antibody, the sections were placed in Target Retrieval Solution (Dako) and heated in an autoclave at $121^{\circ} \mathrm{C}$ for 5 minutes. This pretreatment was not needed for staining with the anti-CD45R/B220, anti-CD14, antiDC, anti-FDC, anti-CD3, anti-clusterin, and anti-protein gene product 9.5 antibodies. After these treatments, the sections were rinsed three times in PBS, blocked again with normal goat serum or normal chicken serum, and then incubated with various antisera against cell surface markers at $4^{\circ} \mathrm{C}$ overnight. The sections were rinsed with PBS, incubated with Alexa Fluor 488-labeled goat anti-rat IgG or chicken anti-goat IgG (diluted 1:400; Invitrogen, Eugene, OR) for 1 hour and counterstained with propidium iodide (PI; Sigma, Saint Louis, MO). The sections were observed by confocal laser microscopy (MRC1024; BioRad, Hercules, CA), and after microscopic observation, the coverslips were removed from the slides and counterstained with Mayer's hematoxylin. To analyze the PrPs distribution of the same position on the section, we reobserved the same section using light microscopy.

\section{Results}

\section{Incorporation and Vicissitude of PrPs into Peyer's Patches}

We investigated sequentially how PrPs administered by the oral route invaded the intestine and then spread.

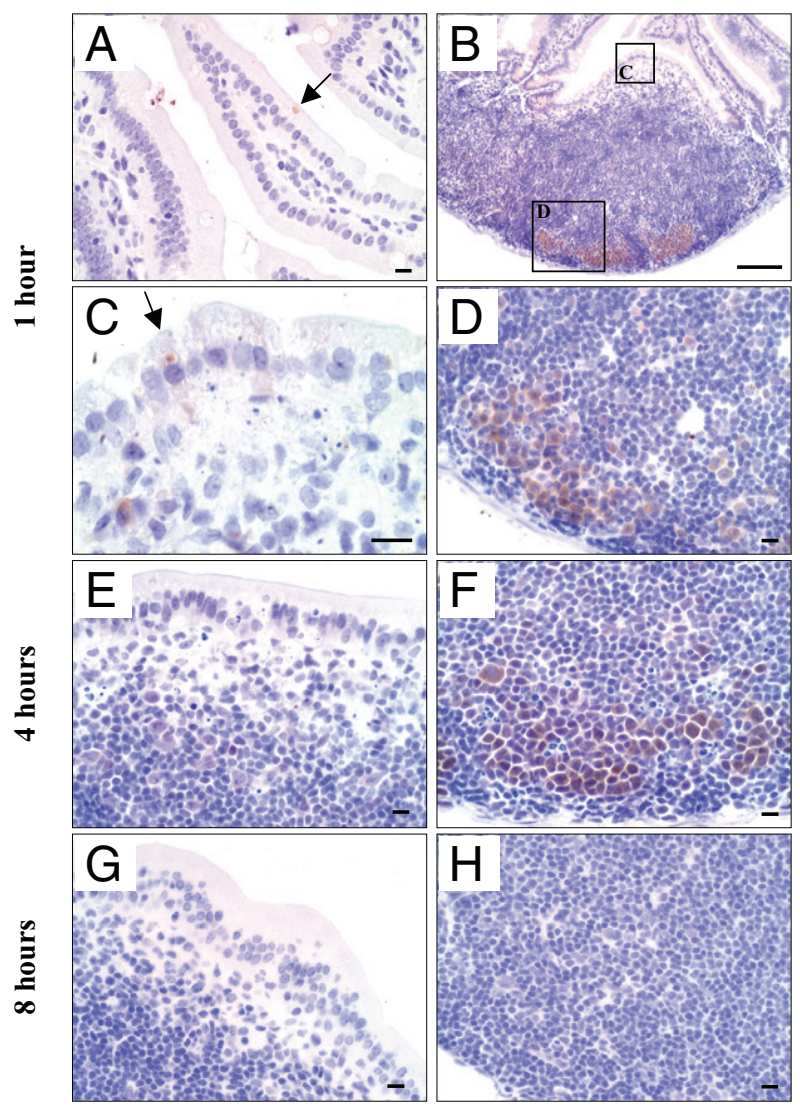

Figure 1. Distribution of orally inoculated prion proteins (PrPs) in the Peyer's patches of the duodenum. Cellular PrP knockout mice were orally challenged with $200 \mu \mathrm{L}$ of $10 \%$ Fukuoka-1 strain Creutzfeldt-Jakob disease brain homogenate. Small intestines were obtained at the indicated times after the challenge and subjected to immunostaining for PrPs. The paraffin sections of Peyer's patches were stained with anti-PrP antibody. Immunohistochemical photographs show the distribution of PrPs in the duodenum villi (A) at 1 hour and in Peyer's patch at 1 hour [B: lower magnification, C: subepithelial dome (SED), D: subfollicle], 4 hours (E: SED, F: subfollicle), and 8 hours (G: SED, H: subfollicle) after the challenge. Arrows indicate epitheliocytes including PrP-positive particle in the villi (A) and follicleassociated epithelium (FAE) (C) at 1 hour after the challenge. Scale bars $=10$ $\mu \mathrm{m}$ 
1304 Takakura et al

AJP September 2011, Vol. 179, No. 3

Table 2. Summary of Distribution of PrP-Positive Cells in Small Intestine Peyer's Patches of $\mathrm{PrP}^{\mathrm{C}}$ Knockout Mice at Various Times after an Oral Challenge

\begin{tabular}{|c|c|c|c|}
\hline $\begin{array}{l}\text { Time after } \\
\text { oral } \\
\text { challenge }\end{array}$ & Duodenum PP & Jejunum PP & Ileum PP \\
\hline 1 hour & VE, FAE, SED, SF & ND & ND \\
\hline 2 hours & - & SED, $\mathrm{F}$ & SED, F \\
\hline 4 hours & SED, SF & SED, F, IFR, SF & IFR \\
\hline 6 hours & ND & SED, F, IFR, SF & $\mathrm{F}, \mathrm{IFR}$, SF \\
\hline 8 hours & ND & SED, F, IFR, SF & ND \\
\hline 10 hours & ND & $\mathrm{F}^{\star}, \mathrm{IFR}^{\star}, \mathrm{SF}^{\star}$ & - \\
\hline 2 days & SED* & $\mathrm{SED}^{*}, \mathrm{~F}^{\star}, \mathrm{SF}^{*}$ & - \\
\hline 6 days & SED* & SED $^{\star}, F^{\star}, \mathrm{IFR}^{\star}$ & ND \\
\hline
\end{tabular}

- , not determined

${ }^{*}$ Only 1 or 2 prion protein (PrP)-positive cells were detected in a photograph.

ND, PrP-positive cells are not detected; F, follicle; FAE, follicle-associated epithelium; IFR, interfollicular region; PP, Peyer's patches; SED, subepithelial dome; SF, subfollicle; VE, villus epithelium.

However, $\mathrm{PrP}^{\mathrm{c}}$ are commonly expressed in several lymphoid tissues and organs besides the brain. Whereas it would be very difficult to detect and trace relatively small amounts of PrPs delivered by the oral route, we used $\mathrm{PrP}^{\circ}$ knockout mice in these experiments to remove the noise of normal $\mathrm{PrP}^{\mathrm{C}}$. Figure 1 shows the distribution of PrPpositive cells in the Peyer's patches of the duodenum. After the oral challenge of 10\% Fukuoka-1 strain CJDinfected brain homogenate to $\mathrm{PrP}^{\circ}$ knockout mice, PrPpositive cells were not detected in any of the samples at 15 or 30 minutes. At 1 hour after the oral challenge, we were able to detect PrP-positive particles in the cytoplasm of villus epitheliocytes and some cells of the FAE (Figure 1, A-C). In the subepithelial dome (SED) of Peyer's patches, PrP-positive cells were also detected (Figure $1, B$ and C). Surprisingly, numerous PrP-positive cells had already accumulated at the subfollicle region of Peyer's patches (Figure 1, B and D). By 4 hours after the
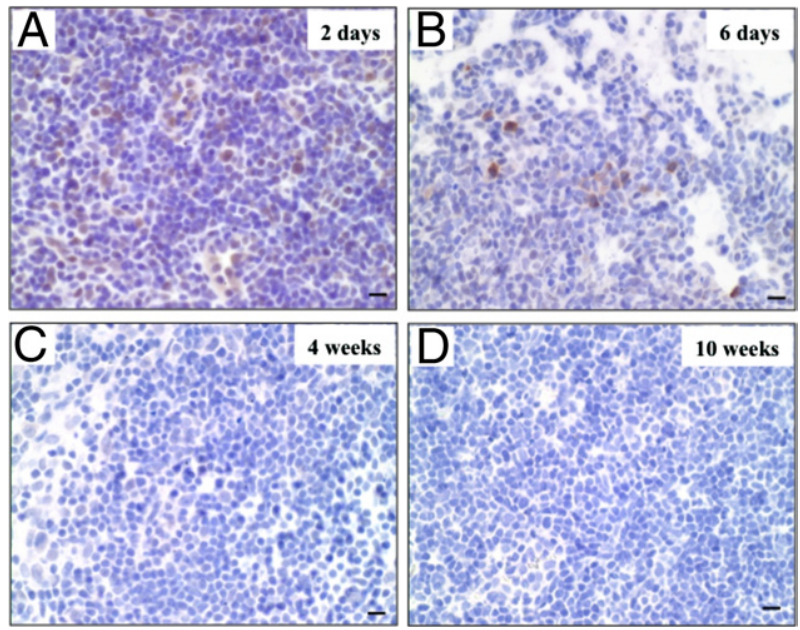

Figure 2. Prion protein $(\mathrm{PrP})$-positive cells in the mesenteric lymph nodes (MLN). Then after oral challenge with 10\% Fukuoka-1 strain Creutzfeldt-Jakob disease brain homogenate, MLN were obtained from cellular $\operatorname{PrP}\left(\operatorname{PrP}^{\mathrm{C}}\right)$ knockout mice at 2 days $(\mathbf{A}), 6$ days $(\mathbf{B}), 4$ weeks $(\mathbf{C})$, and 10 weeks (D). The paraffin sections of MLN were stained with anti-PrP antibody. Scale bars $=10 \mu \mathrm{m}$ challenge, PrP-positive cells were observed in the SED and the subfollicle region of the Peyer's patch, as it was at 1 hour (Figure 1, E and F). However, we could not detect PrP-positive cells in duodenal Peyer's patches later than 8 hours after the challenge (Figure $1, G$ and $H$ ). These results and Supplemental Figure S1 (available at http://ajp.amjpathol.org) additionally indicate that the positive reactions are a specific reaction against orally challenged PrPs with our immunohistochemical method.

Table 2 summarizes the pattern of distribution of PrPpositive cells in the Peyer's patches of the duodenum, jejunum, and ileum after the oral challenge. In the Peyer's patches of the jejunum and ileum, PrP-positive cells were detected 2 hours after the challenge. The number of PrP-positive cells reached a peak in the Peyer's patches of the jejunum and ileum at 4 to 8 hours and at 6 hours after the inoculation, respectively. The pattern of distribution of the PrP-positive cells in the jejunum and ileum was the same as for the Peyer's patches of the duodenum. PrP-positive cells had disappeared from the jejunal and ileal Peyer's patches after 10 hours of the challenge.
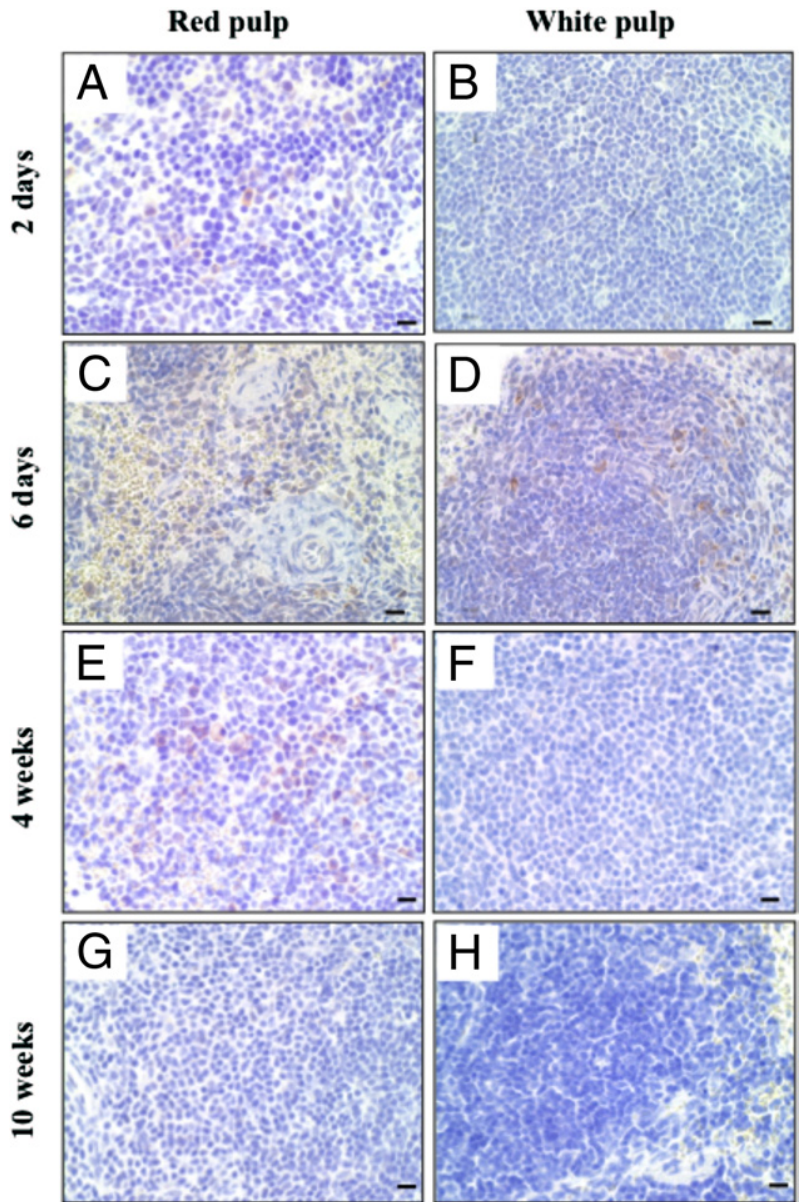

Figure 3. Prion protein ( $\mathrm{PrP}$ )-positive cells in the spleen. Spleens were obtained from cellular PrP knockout mice at 2 days $(\mathbf{A}, \mathbf{B}), 6$ days $(\mathbf{C}, \mathbf{D}), 4$ weeks $(\mathbf{E}, \mathbf{F})$, and 10 weeks $(\mathbf{G}, \mathbf{H})$ after an oral challenge with $10 \%$ Fukuoka-1 strain Creutzfeldt-Jakob disease brain homogenate. The paraffinembedded spleens were stained with anti-PrP antibody. The photographs show the area of red pulp (left column) and white pulp (right column). Scale bars $=10 \mu \mathrm{m}$. 
Table 3. Transition of Number of PrP-Positive Cells Detected in the MLN and Spleen of $\operatorname{PrP}^{\mathrm{C}}$ Knockout Mice at Various Times after an Oral Challenge

\begin{tabular}{ccc}
\hline $\begin{array}{c}\text { Time after oral } \\
\text { challenge }\end{array}$ & MLN & Spleen \\
\hline 2 days & +++ & + \\
6 days & ++ & ++ \\
4 weeks & ND & ++ \\
10 weeks & ND & ND \\
\hline
\end{tabular}

+ , several PrP-positive cells detected;,++ PrP-positive cells detected at an intermediate level; +++ , numerous PrP-positive cells detected.

$\mathrm{MLN}$, mesenteric lymph nodes; ND, PrP-positive cells not detected; PrP, prion protein; $\mathrm{PrP}^{\mathrm{c}}$, cellular prion protein.

\section{Spread of PrP-Positive Cells to Mesenteric Lymph Nodes and Spleen}

Next, we investigated the distribution of PrP-positive cells in the MLN, which was the draining lymph nodes of the Peyer's patches. PrP-positive cells in the MLN were observed mainly around vessels in the follicles and in the interfollicular region (Figure 2, A and B). The number of PrP-positive cells clearly declined between 2 and 6 days after the challenge and then disappeared by 4 weeks after the challenge (Figure 2, A-D).

In the spleen, PrP-positive cells were well detected around vessels until 4 weeks after the challenge and were mainly observed in the red pulp, except for the samples taken on day 6, when the PrP-positive cells were mainly found in the white pulp (Figure 3, A-F). However, PrP-positive cells disappeared from the spleen by 10 weeks after the challenge (Figure $3, \mathrm{G}$ and $\mathrm{H}$ ).

Table 3 summarizes the transition of a number of PrP-positive cells detected in the MLN and spleen.

\section{Duodenum Peyer's patch}
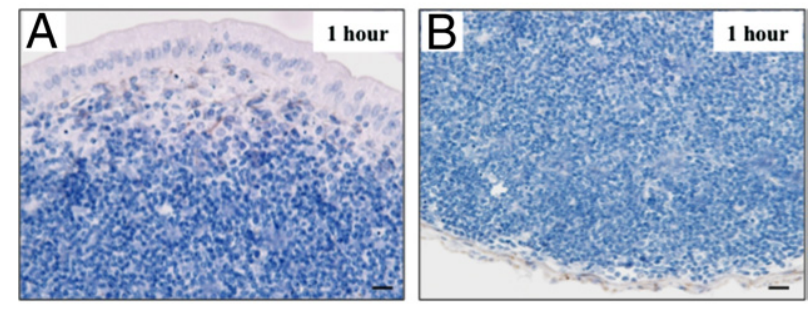

MLN
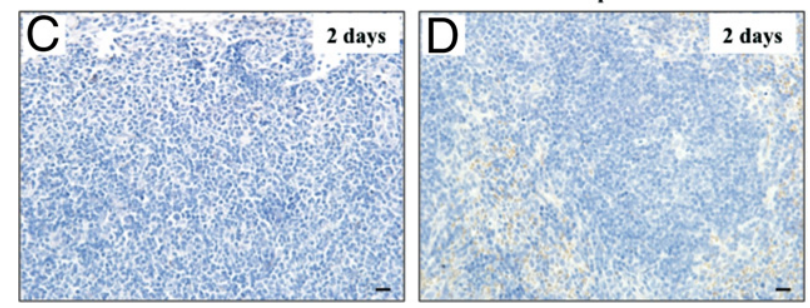

Figure 4. Oral inoculation of normal brain homogenate. Cellular prion protein $\left(\mathrm{PrP}^{\mathrm{c}}\right)$ knockout mice were orally challenged with $200 \mu \mathrm{L}$ of $10 \%$ normal brain homogenate. The small intestines, mesenteric lymph nodes (MLN), and spleen were obtained at the indicated times after the challenge and were subjected to immunostaining for prion proteins (PrPs). Immunohistochemical photographs show subepithelial dome (A) and subfollicle (B) regions of the duodenum Peyer's patch at 1 hour, MLN (C) at 2 days, and spleen (D) at 2 days after the challenge. Scale bars $=10 \mu \mathrm{m}$.
PrP-positive cells were detected in the MLN earlier than in the spleen. The number in the MLN and spleen reached a peak at 2 days and at 6 days after the challenge, respectively. These data imply that there is quite a difference in the period during which PrP-positive cells can be detected between the MLN and the spleen, and that they disappear in the MLN earlier than in the spleen.

\section{Oral Inoculation of Normal Brain Homogenate}

We performed an oral inoculation of normal brain homogenate to $\mathrm{PrP}^{\mathrm{c}}$ knockout mice (Ngsk Prnp ${ }^{\mathrm{O} / 0}$ ). Mice were euthanized at 1 and 2 hours and 2 days after the challenge. Duodenum Peyer's patches, MLN and spleen were obtained from three mice at each time point. PrPpositive cells were detected in the SED of the Peyer's patch at 1 hour (Figure 4A) and 2 hours (not shown) after the challenge. However, the accumulation of PrPpositive cells in the subfollicle region of the Peyer's patch was not observed in any of the time points (Figure 4B). In addition, PrP-positive cells were clearly stained in the MLN and spleen at 2 days after a challenge of 10\% Fukuoka-1 strain CJD (Figures 2 and 3), but not after a challenge of normal brain homogenate (Figure 4, C and D).

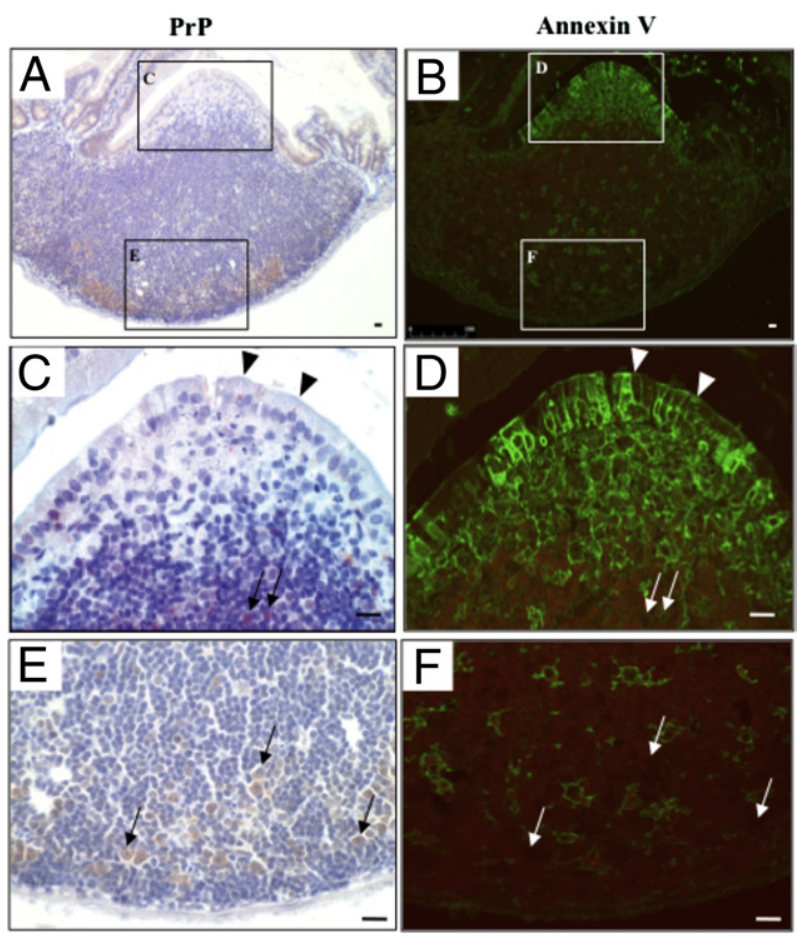

Figure 5. Prion proteins ( $\mathrm{PrP}$ )-positive cells expressing annexin $\mathrm{V}$ in the follicle-associated epithelium. The same paraffin section of duodenum at 1 hour after the oral challenge was immunohistochemically re-stained, initially using anti-PrP antibody (A: with boxed areas magnified in $\mathbf{C}$ and $\mathbf{E}$ ) and then with an anti-annexin $\mathrm{V}$ antibody (B: with boxed areas magnified in $\mathbf{D}$ and $\mathbf{F}$ ). Arrows and arrowheads indicate the same PrP-positive cells. Scale bars = $10 \mu \mathrm{m}$. 

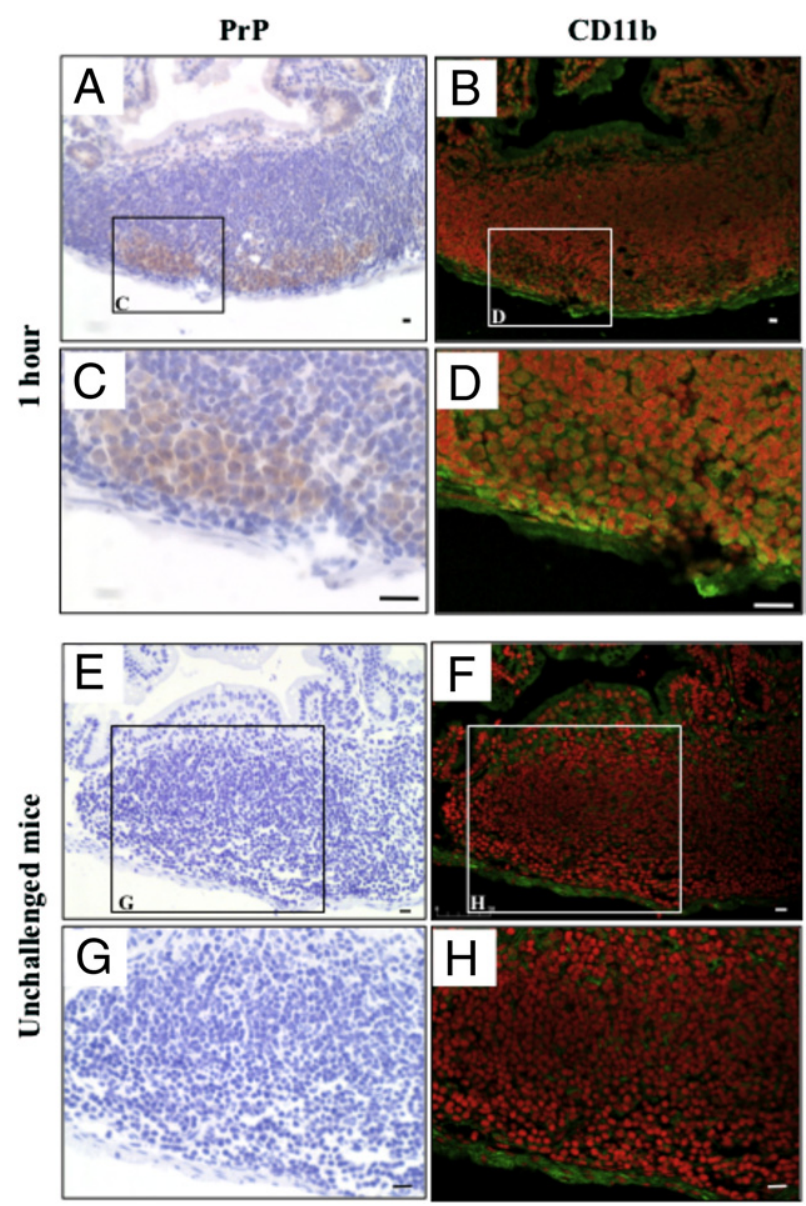

Figure 6. Accumulation of prion protein ( $\mathrm{PrP}$ )-positive macrophages in the subfollicle region of Peyer's patches. The small intestines were obtained from mice at 1 hour after the oral challenge $(\mathbf{A}-\mathbf{D})$ or from unchallenged mice $(\mathbf{E}-\mathbf{H})$. The same paraffin section of the Peyer's patches of the duodenum were immunohistochemically re-stained, initially using an anti-PrP antibody (left column) and then with an anti-CD11b antibody (right column). The boxed areas in $\mathbf{A}, \mathbf{B}, \mathbf{E}$, and $\mathbf{F}$ are enlarged in $\mathbf{C}, \mathbf{D}, \mathbf{G}$, and $\mathbf{H}$, respectively. Scale bars $=10 \mu \mathrm{m}$.

\section{Identification of Cell Types of PrP-Positive Cells in Peyer's Patch}

To identify the cell types of PrP-positive cells in the Peyer's patches of the duodenum, we performed immunohistochemical re-staining using several cell-type specific antibodies. First, we used anti-annexin $\mathrm{V}$ antibodies for microfold (M) cells in the FAE and DCs of the Peyer's patch. ${ }^{27}$ PrP-positive cells were detected in the FAE and SED and accumulated in the subfollicle region of the Peyer's patches at 1 hour after the challenge (Figure 5, C and $\mathrm{E}$ ). Annexin $\mathrm{V}$-positive cells were detected in several parts of the Peyer's patches that we observed (Figure 5B). Epitheliocytes that possessed PrP-positive particles in the FAE were identified as $M$ cells because they expressed annexin $\mathrm{V}$ (arrowheads in Figure 5, C and D). In contrast, PrP-positive cells in the SED and subfollicle regions of the Peyer's patch did not stain for anti-annexin $\mathrm{V}$ antibody. Annexin $\mathrm{V}$ is also a marker for DC (Figure 5, C-F).

PrP-positive cells were found in the subfollicle region of Peyer's patches, in cells that were also positive for the monocyte marker CD11b (otherwise known as macrophage-1 antigen) (Figure 6, A-D). CD11b-positive cells in Peyer's patches of unchallenged mice were usually localized in the SED and interfollicular region, but not in the subfollicle region (Figure $6, \mathrm{E}-\mathrm{H}$ ). In addition, we stained $\mathrm{B}$ cells, $\mathrm{T}$ cells, and FDCs in duodenal Peyer's patches with antibodies for CD45R/B220, ${ }^{23}$ CD3, ${ }^{26}$ and clusterin, ${ }^{28}$ respectively. Figure 7 shows that the PrP-positive cells were entirely negative for these antibodies. These results indicate that orally delivered PrPs were transported to SED by M cells, and that CD11b-posititve cells incorporated PrPs and instantly migrated to the subfollicle region of the Peyer's patch.

\section{Identification of PrP-Positive Cell Types in the Spleen}

Cryosections of the spleen at 2 days after the oral challenge were used for immunohistochemical re-staining to identify PrP-positive cell types. A re-staining study revealed that CD14-positive cells were PrP-positive, and that $\mathrm{B}$ cells (CD45R/B220), FDCs, ${ }^{30}$ and $\mathrm{DCs}^{31}$ were PrP-negative (Figure 8). It has been reported that monocytes and macrophages mainly express the CD14 antigen in the spleen. ${ }^{24}$ These results indicate that PrP-positive cells in the spleen are CD14-positive macrophages.
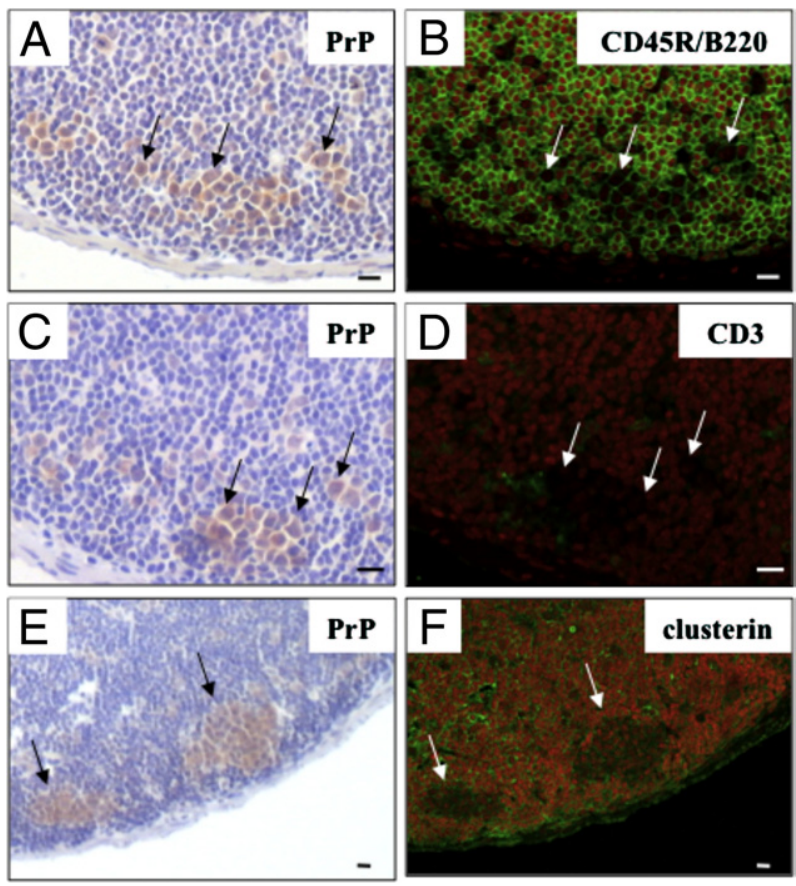

Figure 7. Other cell types of the Peyer's patches of the duodenum did not stain for prion proteins (PrPs). The same paraffin section of the duodenum Peyer's patches at 1 hour after the oral challenge were immunohistochemically re-stained, initially using an anti-PrP antibody $(\mathbf{A}, \mathbf{C}, \mathbf{E})$ and then with anti-CD45R/B220 (B), anti-CD3 (D), or anti-clusterin (F) antibodies. Arrows indicate the same PrP-positive cells. Scale bars $=10 \mu \mathrm{m}$. 


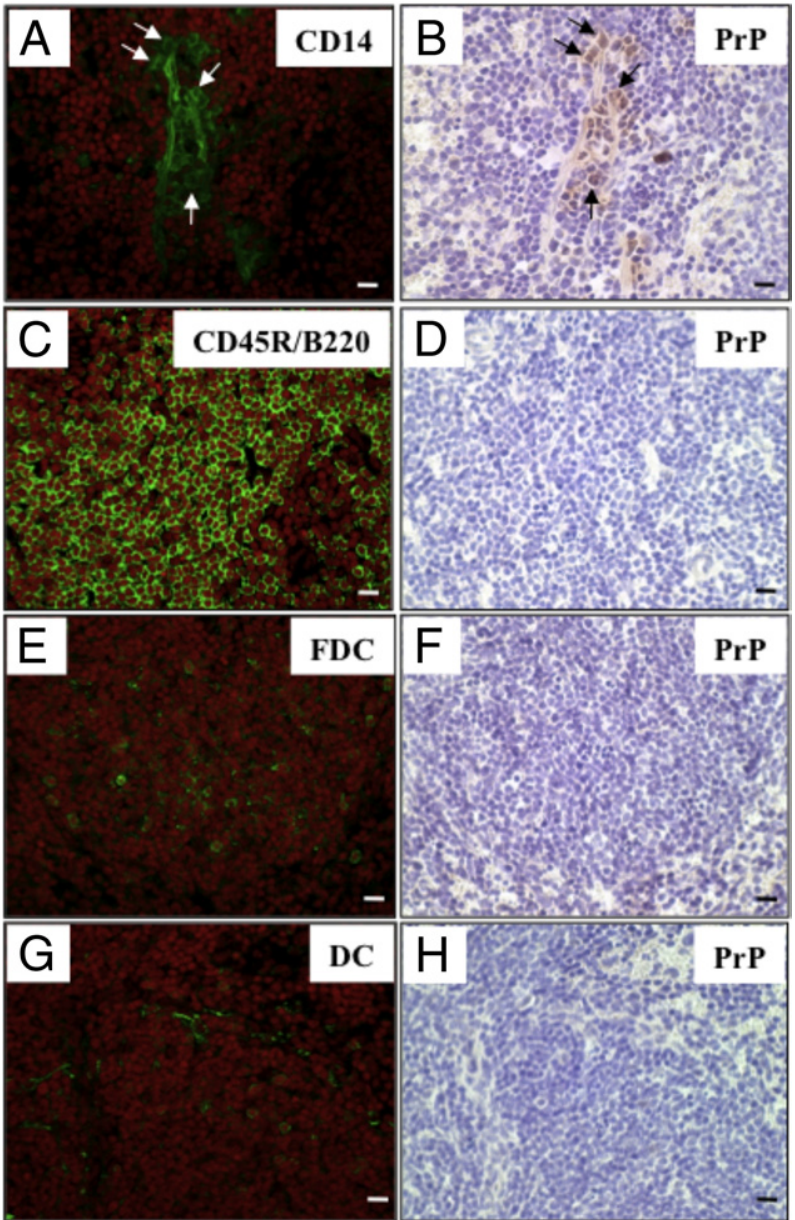

Figure 8. Immunohistochemical re-staining of various cell surface markers and prion proteins (PrPs) in the spleen. The same frozen sections of spleen at 2 days after the oral challenge were immunohistochemically re-stained, initially using an anti-PrP antibody $(\mathbf{B}, \mathbf{D}, \mathbf{F}, \mathbf{H})$ and then with anti-CD14 (A) anti-CD45R/B220 (C), anti-follicular dendritic cells (FDC) (E) and anti-dendritic cell (DC) (G) antibodies. Arrows indicate the same PrP-positive cells. Scale bars $=10 \mu \mathrm{m}$

\section{Potential Contacts between PrP-Positive Cells and Nerve Fibers in Peyer's Patches and the Spleen}

We investigated the possibility of direct contact between PrP-positive cells and peripheral nerve fibers in Peyer's patches and the spleen. Immunohistochemical re-staining was performed using a neuron specific anti-protein gene product 9.5 antibody. ${ }^{32}$ In the subfollicle region of Peyer's patches at 4 hours after the oral challenge, we detected PrP-positive cells close to the nerve fiber (Figure 9, A and B). Nerve fibers were also detected in the vicinity of PrP-positive cells (dotted circle). In the spleen, 2 days after the challenge, the nerve fibers were detected in association with blood vessels in the red pulp and PrP-positive cells were found nearby (Figure 9, C and D).

\section{Discussion}

In this study, we have focused on the early stages of alimentary TSE infection and we have tried to identify the cells involved in the entry and spread of PrPs. We first observed the uptake and internalization of orally delivered PrPs by annexin V-positive $M$ cells within the FAE. Several in vivo $^{33}$ and in vitro ${ }^{9,34}$ studies suggest that $M$ cells act as the portal sites for orally administered infectious agents. Additionally, we observed that villous epithelial cells also incorporated PrPs. This epitheliocyte might be an $\mathrm{M}$ cell existing in the villi. ${ }^{35}$ Therefore, we suggest that following the uptake and transportation of orally delivered PrPs by M cells, the PrPs are transferred from $M$ cells to macrophages in the SED. Thereafter, these macrophages migrate and accumulate into the subfollicle region of Peyer's patches, and are close to the nerve fibers within a few hours after the oral challenge. It has been reported that there are almost no differences in early stage pathology between Ngsk Prnp ${ }^{\mathrm{O} / \mathrm{O}}$ mice and wild-type mice. ${ }^{36}$ In addition, several proteins have been shown to interact with prion proteins, including laminin, $\mathrm{N}-\mathrm{CAM}$, a cell surface component with an important role in neuronal aggregation, and tyrosine kinase Fyn implicating a role of PrP in cell signaling. ${ }^{37}$ Therefore, the uptake of orally challenged PrPs from alimentary tract and its spread to the peripheral lymph nodes or spleen are not dependent on the $\mathrm{PrP}^{\mathrm{c}}$ expression in mice.

Peyer's patches have a very good blood supply and lymph drainage. ${ }^{38}$ PrP-positive macrophages may enter the lymph ducts in Peyer's patches, migrate to the MLN, and finally reach the spleen through the blood circulation. Additionally, there is a possibility that PrP-positive macrophages may reach spleen directly through the blood circulation from the Peyer's patches. However, PrP-positive cells are likely to mainly spread to the MLN, because PrP-positive cells were detected in the MLN earlier than the spleen in this study. Following these movements, PrP-positive macrophages accumulated mainly in the red
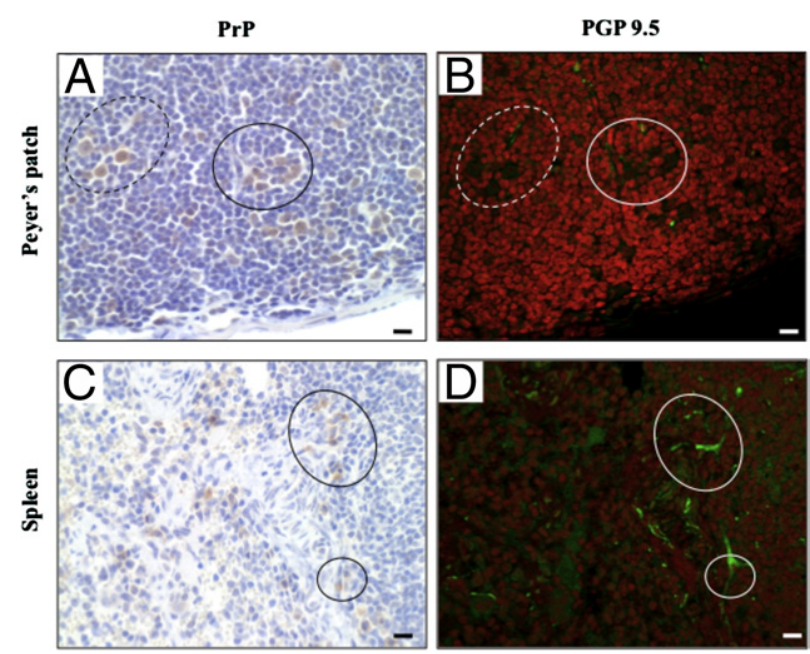

Figure 9. Immunohistochemical re-staining of prion proteins (PrPs) and nerve fibers in Peyer's patches and the spleen. The samples of Peyer's patches and spleen were obtained from mice at 4 hours and 2 days after an oral challenge, respectively. The same paraffin sections were immunohistochemically re-stained initially using an anti-PrP antibody $(\mathbf{A}, \mathbf{C})$ and then with an anti-protein gene product 9.5 antibody $(\mathbf{B}, \mathbf{D})$. Dotted and solid circles in the left column correspond to those in the right column. Scale bars $=10 \mu \mathrm{m}$ 
pulp of the spleen, where they may have contact with peripheral nerve fibers.

We observed that PrP-positive cells immediately accumulated in the subfollicle region of Peyer's patches in the duodenum at 1 hour and in the jejunum and ileum at 2 hours after the oral challenge. Other groups have reported that orally delivered PrPSc in hamsters and sheep were observed in Peyer's patches at 4 days $^{39}$ and 1 month ${ }^{40}$ after an oral challenge, respectively. In scrapie and BSE infected mice, PrPSc was observed in Peyer's patches at 45 days after the oral challenge. ${ }^{10}$ In these reports, PrPSc might be observed in Peyer's patches after its replication and circulation because PrPs immunoreactivity could not be detected after 8 hours after the oral challenge in the present experiment (Table 2). As far as we are aware, there have been no reports detailing such a short period after an oral challenge of $\mathrm{PrP}^{\mathrm{Sc}}$, as in the present experiment.

When mice were orally challenged with normal brain homogenate, PrPs were detected only in the SED of Peyer's patches at 1 and 2 hours after the challenge. Normal brain homogenate contains a large amount of $\operatorname{PrP}^{\mathrm{c}}$, however, $\operatorname{PrP}^{c}$ may be largely digested in the gastrointestinal tract. ${ }^{41}$ In addition, Almeida et al ${ }^{42}$ report that macrophages from mice with depletion of the Prnp gene show higher rates of phagocytosis than wild-type macrophages in in vitro and in vivo assays, and that the activation of ERK-1/2 and Akt kinase induce various biological responses of macrophages in PrP-knockout mouse. ${ }^{43}$ Dendritic cells and macrophages in SED would immediately degrade incorporated $\operatorname{PrP}^{\mathrm{C}} .44,45$ These results indicate that the undigested $\mathrm{PrPSc}^{\mathrm{S}}$ may induce the accumulation of PrP-positive cells in the subfollicle region of Peyer's patches and their spread to the MLN and the spleen.

We reveal here that PrP-positive cells both in Peyer's patches and the spleen were macrophages. Macrophages containing PrPSc have been detected in ovine Peyer's patches, ${ }^{46}$ other secondary lymph nodes of variant CJD patients, ${ }^{47}$ and the spleen of mice. ${ }^{48}$ In the spleen, PrP-positive cells were entirely CD14-positive macrophages (Figure 8). Jeffrey et al ${ }^{48}$ revealed that such macrophages contained PrPSc within lysosomes. Additionally, the depletion of spleen macrophages by administrating clodronate to mice shows that macrophages partly control scrapie infection in peripheral tissues by sequestration of the scrapie inoculum and impairment of the replication of scrapie infectious agents in the spleen during the early stages of the disease. ${ }^{45}$

$\mathrm{DCs}^{49}$ and macrophages ${ }^{50}$ in Peyer's patches were previously reported to express the CD11b molecule. In addition, it has also been reported that only DCs in Peyer's patches expressed annexin V. ${ }^{27}$ PrP-positive cells in Peyer's patches did not express annexin $V$ in our study (Figure 5). Therefore, we suggest that PrP-positive cells in Peyer's patches are CD11b-positive and annexin Vnegative macrophages. Surprisingly, in the Peyer's patches of the duodenum of unchallenged $\operatorname{PrP}^{\mathrm{C}}$ knockout mice, CD11b-positive cells were detected in the SED, but few in the subfollicle region (Figure 6). These results raise the possibility that the accumulation of CD11b-posiitve cells to the subfollicle region may have occurred specifically when they acquired orally delivered PrPs.

The present study also examined the potential for contact between PrP-positive cells and nerve fibers in Peyer's patches and the spleen. We readily detected PrPpositive cells in the vicinity of the nerve fibers in the subfollicle region of the Peyer's patch at 4 hours and in the spleen at 2 days after the challenge (Figure 9). It has been reported that the relative positioning of infected cells and nerve fibers control the efficiency of peripheral prion neuroinvasion. ${ }^{51}$ These contacts in the peripheral lymph nodes and spleen are assumed to be important for neuroinvasion of the infectious agent. ${ }^{52,53}$ Therefore, these findings suggest the possibility that PrP-positive macrophages in Peyer's patches and the spleen may be involved in neuroinvasion, and neuroinvasion can occur a few hours after an oral infection.

\section{References}

1. Aguzzi A: Prion diseases of humans and farm animals: epidemiology, genetics and pathogenesis. J Neurochem 2006, 97:1726-1739

2. Masters CL, Richardson EP Jr: Subacute spongiform encephalopathy (Creutzfeldt-Jakob Disease). The nature and progression of spongiform change. Brain 1978, 101:333-344

3. van Everbroeck B, Dobbeleir I, De Waele M, De Leenheir E, Lubke U, Martin JJ, Cras P: Extracellular protein deposition correlates with glial activation and oxidative stress in Creutzfeldt-Jakob and Alzheimer's disease. Acta Neuropathol 2004, 108:194-200

4. van Keulen LJ, Vromans ME, Dolstra $\mathrm{CH}$, Bossers A, van Zijderveld FG: Pathogenesis of bovine spongiform encephalopathy in sheep. Arch Virol 2008, 153:445-453

5. Bolton DC, McKinley MP, Prusiner SB: Identification of a protein that purifies with the scrapie prion. Science 1982, 218:1309-1311

6. Hill AF, Desbruslais M, Joiner S, Sidle KC, Gowland I, Collinge J, Doey LJ, Lantos P: The same prion strain causes VCJD and BSE. Nature 1997, 389:448-450

7. Mabbott N, Turner M: Prions and the blood and immune systems Haematologica 2005, 90:542-548

8. Neutra MR, Frey A, Kraehenbuhl JP: Epithelial M cells: gateways for mucosal infection and immunization. Cell 1996, 86:345-348

9. Heppner FL, Christ AD, Klein MA, Prinz M, Fried M, Kraehenbuhl JP, Aguzzi A: Transepithelial prion transport by M cells. Nat Med 2001, 7:976-977

10. Maignien T, Lasmézas Cl, Beringue V, Dormont D, Deslys JP: Pathogenesis of the oral route of infection of mice with scrapie and bovine spongiform encephalopathy agents. J Gen Virol 1999, 80:3035-3042

11. Vulchanova L, Casey MA, Crabb GW, Kennedy WR, Brown DR: Anatomical evidence for enteric neuroimmune interactions in Peyer's patches. J Neuroimmunol 2007, 185:64-74

12. McBride PA, Schulz-Schaeffer WJ, Donaldson M, Bruce M, Diringer $H$, Kretzschmar $H A$, Beekes $M$ : Early spread of scrapie from the gastrointestinal tract to the central nervous system involves autonomic fibers of the splanchnic and vagus nerves. J Virol 2001, 75: 9320-9327

13. Andréoletti $O$, Berthon $P$, Marc D, Sarradin P, Grosclaude J, van Keulen L, Schelcher F, Elsen JM, Lantier F: Early accumulation of $\mathrm{PrP}^{\mathrm{Sc}}$ in gut-associated lymphoid and nervous tissues of susceptible sheep from a Romanov flock with natural scrapie. J Gen Virol 2000 , 81:3115-3126

14. Carp RI, Callahan SM: In vitro interaction of scrapie agent and mouse peritoneal macrophages. Intervirology 1981, 16:8-13

15. Huang FP, Platt N, Wykes M, Major JR, Powell TJ, Jenkins CD, MacPherson GG: A discrete subpopulation of dendritic cells transports apoptotic intestinal epithelial cells to $T$ cell areas of mesenteric lymph nodes. J Exp Med 2000, 191:435-444

16. Huang FP, Farquhar CF, Mabbott NA, Bruce ME, MacPherson GG: Migrating intestinal dendritic cells transport PrPSc from the gut. J Gen Virol 2002, 83:267-271 
17. Kitamoto T, Muramoto T, Mohri S, Doh-Ura K, Tateishi J: Abnormal isoform of prion protein accumulates in follicular dendritic cells in mice with Creutzfeldt-Jakob disease. J Virol 1991, 65:6292-6295

18. Miyazawa K, Kanaya T, Tanaka S, Takakura I, Watanabe K, Ohwada S, Kitazawa H, Rose MT, Sakaguchi S, Katamine S, Yamaguchi T, Aso $\mathrm{H}$ : Immunohistochemical characterization of cell types expressing the cellular prion protein in the small intestine of cattle and mice. Histochem Cell Biol 2007, 127:291-301

19. Sakaguchi S, Katamine S, Shigematsu K, Nakatani A, Moriuchi R, Nishida N, Kurokawa K, Nakaoke R, Sato H, Jishage K, Kuno J, Noda $\mathrm{T}$, Miyamoto $\mathrm{T}$ : Accumulation of proteinase K-resistant prion protein (PrP) is restricted by the expression level of normal PrP in mice inoculated with a mouse-adapted strain of the Creutzfeldt-Jakob disease agent. J Virol 1995, 69:7586-7592

20. Li A, Sakaguchi S, Shigematsu K, Atarashi R, Roy BC, Nakaoke R, Arima K, Okimura N, Kopacek J, Katamine S: Physiological expression of the gene for PrP-like protein. PrPLP/Dpl, by brain endothelial cells and its ectopic expression in neurons of PrP-deficient mice ataxic due to purkinje cell degeneration Am J Pathol 2000, 157:14471452

21. Moore CR, Mastrangelo P, Bouzamondo E, Heinrich C, Legname G, Prusiner SB, Hood L, Westaway D, DeArmond JS, Tremblay P: Doppel-induced cerebellar degeneration in transgenic mice. Proc Natl Acad Sci USA: 2001, 98:15288-15293

22. Tuzi NL, Gall E, Melton D, Manson JC: Expression of doppel in the CNS of mice does not modulate transmissible spongiform encephalopathy disease. J Gen Virol 2002, 83:705-711

23. Coffman RL: Surface antigen expression and immunoglobulin gene rearrangement during mouse pre-B cell development. Immunol Rev 1982, 69:5-23

24. Matsuura K, Ishida T, Setoguchi M, Higuchi Y, Akizuki S, Yamamoto S: Upregulation of mouse CD14 expression in Kupffer cells by lipopolysaccharide. J Exp Med 1994, 179:1671-1676

25. Whiteland JL, Nicholls SM, Shimeld C, Easty DL, Williams NA, Hill TJ: Immunohistochemical detection of T-cell subsets and other leukocytes in paraffin-embedded rat and mouse tissues with monoclonal antibodies. J Histochem Cytochem 1995, 43:313-320

26. Owen JL, Iragavarapu-Charyulu V, Gunja-Smith Z, Herbert LM, Grosso JF, Lopez DM: Up-regulation of matrix metalloproteinase-9 in T lymphocytes of mammary tumor bearers: role of vascular endothelial growth factor. J Immunol 2003, 171:4340-4351

27. Verbrugghe P, Waelput W, Dieriks B, Waeytens A, Vandesompele J, Cuvelier CA: Murine M cells express annexin V specifically. J Pathol 2006, 209:240-249

28. Huber C, Thielen C, Seeger H, Schwarz P, Montrasio F, Wilson MR, Heinen E, Fu YX, Miele G, Aguzzi A: Lymphotoxin-beta receptordependent genes in lymph node and follicular dendritic cell transcriptomes. J Immunol 2005, 174:5526-5536

29. Tateishi J, Ohta M, Koga M, Sato Y, Kuroiwa Y: Transmission of chronic spongiform encephalopathy with kuru plaques from humans to small rodents. Ann Neurol 1979, 5:581-584

30. Balogh P, Aydar Y, Tew JG, Szakal AK: Appearance and phenotype of murine follicular dendritic cells expressing VCAM-1. Anat Rec 2002, 268:160-168

31. Breel M, Mebius RE, Kraal G: Dendritic cells of the mouse recognized by two monoclonal antibodies. Eur J Immunol 1987, 17:1555-1559

32. Thompson RJ, Doran JF, Jackson P, Dhillon AP, Rode J: PGP 9.5 a new marker for vertebrate neurons and neuroendocrine cells. Brain Res 1983, 278:224-228

33. Beekes M, McBride PA: Early accumulation of pathological PrP in the enteric nervous system and gut-associated lymphoid tissue of hamsters orally infected with scrapie. Neurosci Lett 2000, 278:181-184

34. Miyazawa K, Kanaya T, Takakura I, Tanaka S, Hondo T, Watanabe H, Rose MT, Kitazawa H, Yamaguchi T, Katamine S, Nishida N, Aso H: Transcytosis of murine-adapted BSE agent in an in vitro bovine $\mathrm{M}$ cell model. J Virol 2010, 84:12285-12291
35. Nochi T, Yuki Y, Matsumura A, Mejima M, Terahara K, Kim DY, Fukuyama S, Iwatsuki-Horimoto K, Kawaoka Y, Kohda T, Kozaki S, Igarashi $\mathrm{O}$, Kiyono $\mathrm{H}$ : A novel M cell-specific carbohydrate-targeted mucosal vaccine effectively induces antigen-specific immune responses. J Exp Med 2007, 204:2789-2796

36. Mabbott NA, MacPherson GG: Prions and their lethal journey to the brain. Nat Rev Mcirobiol 2006, 4:201-211

37. Vana K, Zuber C, Nikles D, Weiss S: Novel aspects of prions, their receptor molecules, and innovative approaches for TSE therapy. Cell Mol Neurobiol 2007, 27:107-128

38. Ma B, von Wasielewski R, Lindenmaier W, Dittmar KE: Immunohistochemical study of blood and lymphatic vasculature and the innervation of mouse gut and gut-associated lymphoid tissue. Anat Histol Embryol 2007, 36:62-74

39. Bergström AL, Jensen TK, Heegaard PM, Cordes $H$, Hansen VB, Laursen $\mathrm{H}$, Lind $\mathrm{P}$ : Short-term study of the uptake of $\mathrm{PrP}^{\mathrm{Sc}}$ by the Peyer's patches in hamsters after oral exposure to scrapie. J Comp Pathol 2006, 134:126-133

40. van Keulen LJ, Vromans ME, van Zijderveld FG: Early and late pathogenesis of natural scrapie infection in sheep. APMIS 2002, 110:23-32

41. Scherbel C, Pichner R, Groschup MH, Mueller-Hellwig S, Scherer S Dietrich R, Maertlbauer E, Gareis M: Degradation of scrapie associated prion protein (PrPSc) by the gastrointestinal microbiota of cattle. Vet Res 2006, 37:695-703

42. de Almeida CJ, Chiarini LB, da Silva JP, E Silva PM, Martins MA, Linden R: The cellular prion protein modulates phogocytosis and inflammatory response. J Leukoc Biol 2005, 77:238-246

43. Krebs B, Dorner-Ciossek C, Schmalzbauer R, Vassallo N, Herms J, Kretzschmer HA: Prion protein induced signaling cascades in monocytes. Biochem Biophys Res Commun 2006, 340:13-22

44. Luhr KM, Wallin RP, Lunggren HG, Low P, Taraboulos A, Kristensson $\mathrm{K}$ : Processing and degradation of exogenous prion protein by CD11c(+) myeloid dendritic cells in vitro. J Virol 2002, 23:1225912264

45. Beringue V, Demoy M, Lasmézas Cl, Gouritin B, Weingarten C, Deslys JP, Andreux JP, Couvreur P, Dormont D: Role of spleen macrophages in the clearance of scrapie agent early in pathogenesis. J Pathol 2000, 190:495-502

46. Heggebø R, Press CM, Gunnes G, Lie KI, Tranulis MA, Ulvund M, Groschup $\mathrm{MH}$, Landsverk T: Distribution of prion protein in the ileal Peyer's patch of scrapie-free lambs and lambs naturally and experimentally exposed to the scrapie agent. J Gen Virol 2000, 81:23272337

47. Hilton DA, Ghani AC, Conyers L, Edwards P, McCardle L, Ritchie D, Penney M, Hegazy D, Ironside JW: Prevalence of lymphoreticular prion protein accumulation in UK tissue samples. J Pathol 2004 , 203:733-739

48. Jeffrey M, McGovern G, Goodsir CM, Brown KL, Bruce ME: Sites of prion protein accumulation in scrapie-infected mouse spleen revealed by immuno-electron microscopy. J Pathol 2000, 191:323-332

49. Iwasaki A, Kelsall BL: Unique functions of CD11b+. CD8 $\alpha+$, and double-negative Peyer's patch dendritic cells. J Immunol 2001, 166 : 4884-4890

50. Bland PW, Whiting CV: Differential control of major histocompatibility complex class II I-EK alpha protein expression in the epithelium and in subsets of lamina propria antigen-presenting cells of the gut. Immunology 1993, 79:107-111

51. Prinz M, Heikenwalder M, Junt T, Schwarz P, Glatzel M, Heppner FL, Fu YX, Lipp M, Aguzzi A: Positioning of follicular dendritic cells within the spleen controls prion neuroinvasion. Nature 2003, 425:957-962

52. Dorban G, Defaweux V, Demonceau C, Flandroy S, van Lerberghe PB, Falisse-Poirrier N, Piret J, Heinen E, Antoine N: Interaction between dendritic cells and nerve fibres in lymphoid organs after oral scrapie exposure. Virchows Arch 2007, 451:1057-1065

53. Glaysher BR, Mabbott NA: Role of the GALT in scrapie agent neuroinvasion from the intestine. J Immunol 2007, 178:3757-3766 